[Regular Paper]

\title{
Titanium Modified USY Zeolite-based Catalysts for Hydrocracking Residual Oil (Part 3) Preparation and Activity Test of Catalysts Based on Realuminated USY
}

\author{
Kosaku HonnA $^{\dagger 1), \dagger 3) *}$, Yasuyuki Araki ${ }^{\dagger 1)}$, Toshiyuki Enomoto ${ }^{\dagger 1)}$, Masao Yoshimoto $^{\dagger 1)}$, \\ Yoichi NisHIMURA $^{\dagger 2)}$, and Hiromichi SHIMADA ${ }^{\dagger 2)}$ \\ †1) Japan Cooperation Center, Petroleum (JCCP), 3-2-1 Sakado, Takatsu-ku, Kawasaki 213-0012, JAPAN \\ $\dagger^{2)}$ National Institute of Advanced Industrial Science and Technology (AIST), 1-1-1 Higashi, Tsukuba, Ibaraki 305-0031, JAPAN
}

(Received May 13, 2004)

\begin{abstract}
A high Si/Al ratio USY zeolite with high mesoporosity was used as the starting material for hydrocracking catalysts for residual oil to improve the catalytic selectivity for middle distillate fractions. Realumination of high $\mathrm{Si} / \mathrm{Al}$ USY zeolite without destruction of the zeolitic framework and mesoporous structure was achieved by treating the USY zeolite in an aqueous solution of $\mathrm{NaAlO}_{2}$ after immersion in ethyl alcohol. Subsequently, titanium modification of the realuminated zeolite was carried out using an ethyl alcohol solution of titanium isopropoxide, followed by loading of molybdenum by equilibrium adsorption using an aqueous solution of ammonium paramolybdate. The resultant USY zeolite-based catalysts (MTAZ) showed higher selectivity for middle distillate fractions than previously reported titanium-modified USY zeolite-based catalysts in the hydrocracking of Arabian heavy atmospheric residue. Considering the characteristics of the catalysts, the acid sites on the MTAZ catalysts were mainly located on the mesopore surfaces and the production of gaseous and naphtha fractions was minimized because of the low number of acid sites inside the micropores.
\end{abstract}

\section{Keywords}

Hydrocracking, Realuminated USY zeolite, Titanium modification, Residual oil, Mesopore,

Molybdenum catalyst

\section{1. 緒言}

我が国へ供給される原油は中長期的に重質化が予想される一 方, 需要面では軽油・ガソリンなど輸送燃料の割合が相対的に 高まると想定されている。また，環境負荷低減の視点から輸送 燃料の規格は厳しくなりつつあり, 製品の超低硫黄化, 低芳香 族化などが求められている ${ }^{1,2)}$ 。このような状況下，水素化分 解プロセスは流動接触分解 (FCC) プロセスと比べて重質油か ら効率よく高品質のガソリン・軽油基材を生成可能な分解プロ セスとして期待されている3)。事実，留出油である減圧軽油に ついては世界各国で多くの固定床水素化分解装置が稼動してい る ${ }^{4,5)}$ 。特に, 供給原油が重質である一方, 軽油に対する需要 が高い我が国では，重質油対策技術研究組合を中心として中間 留分増産に向けた残油水素化分解触媒の開発が精力的に行われ た。その結果, 中間留分増産のために重油直接脱硫装置の一部 に水素化分解触媒を充填する技術が開発されたが6) 99)，コーク 前駆体など触媒被毒成分を多く含む残油に対して高い分解活性 を持続する固定床触媒は未開発となっている。海外諸国を見渡 しても, 残油の水素化分解には粉末触媒の利用をべースとする 膨張床，スラリー床など通常の固定床以外のプロセスが用いら

\footnotetext{
* To whom correspondence should be addressed.

${ }^{\dagger 3)}$ (Present) 6-3-5 Aobadai, Ichihara, Chiba 299-0117, JAPAN
}

$$
\text { れている4)。 }
$$

我々のグループは, 重質油対策技術研究組合に引き続き, 固 定床に応用可能な残油水素化分解用触媒の開発を行ってきた。 その結果, チタン修飾USYゼオライトにモリブデンを担持し た触媒（MTZ）が，アラビアンヘビー常圧残油（AH-AR）の 水素化分解反応に扔いて $\mathrm{AR}$ 分解率, 脱アスファルテン率に加 えて中間留分選択性にも優れた性能を示すことを第 1 報10) およ び特許 ${ }^{11)}$ で明らかにした。続いて第2 報12) では, MTZとアル ミナバインダーから $0.8 \mathrm{~mm}$ (1/32 インチ) 径の円筒型成型触 媒担体を製造し，さらにニッケル，モリブデンを担持した固定 床用 Ni-Mo/MTZ- $\mathrm{Al}_{2} \mathrm{O}_{3}$ 触媒を調製した。ベンチスケールユ ニットを用いて約 850 時間に及ぶ活性評価試験を行った結果， $\mathrm{Ni}-\mathrm{Mo} / \mathrm{MTZ}-\mathrm{Al}_{2} \mathrm{O}_{3}$ 触媒は安定した性能を示し, 中間留分選択性 においてチタン修飾を行わない $\mathrm{Ni}-\mathrm{Mo} / \mathrm{USY}-\mathrm{Al}_{2} \mathrm{O}_{3}$ 触媒と比べて 優れていることが明らかとなった。また，チタン修飾USYゼ オライト触媒の構造 ·物性解析の結果 ${ }^{10), 12)}$, 優れた AR 分解率, 脱アスファルテン率は主としてチタン修飾により向上したモリ ブデン硫化物の水素化活性に起因すること, 中間留分選択性が 主としてUSYゼオライトの豊富なメソポアに起因することが 分かった。

本研究ではMTZのさらなる中間留分選択性向上を目的とし て, メソポア容積がさらに大きなゼオライトを出発原料とした モリブデン担持チタン修飾USYゼオライト触媒を調製し, そ 
の活性評価を行った。Y 型ゼオライトのメソポアはスチーミン グ，酸処理などの脱アルミニウム工程を経て調製されることか ら，メソポア容量の大きいゼオライトは Si/A1比が高くなり, 酸量は著しく少なくなる。したがって, 触媒に固体酸性を付与 するためには，ゼオライト骨格へのアルミニウム再挿入（Al 再抻入) が必要である。また, メソポア表面上への選択的な $\mathrm{Al}$ 再挿入が可能であれば, 中間留分選択性低下の原因となる ナフサ, ガス生成サイトとなるマイクロポア内酸点の抑制が期 待される。

ゼオライト骨格への $\mathrm{Al}$ 再挿入については, 数例の報告があ

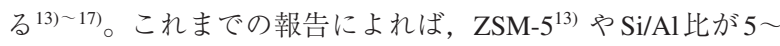
20 程度の $\mathrm{Y}$ 型ゼオライト ${ }^{14), 15)}$ には $\mathrm{Al}$ 再挿入が可能であり, ア ルミニウムの挙動追跡には ${ }^{27} \mathrm{Al}$-MASNMR（magic-angle spinning nuclear magnetic resonance) が有効 ${ }^{16)}$ とされている。一方, 高 Si/Al 比USYゼオライトについては, 通常の Al 再挿入は結晶 破壊を招くことが報告されており ${ }^{17)}$ ，ゼオライト構造を維持し た状態での $\mathrm{Al}$ 再挿入による酸点付与の報告は見あたらない。

本研究では，まず実質的に酸点を持たない高 Si/Al 比USY ゼ オライトを出発原料として, 残油水素化分解触媒に必要となる 酸点の導入を検討した。特に, 結晶構造, メソポア構造を破壊 することなしにメソポア表面へ $\mathrm{Al}$ が再挿入される条件を検討 した。ついで，Al再挿入したUSYゼオライトをチタン修飾し， モリブデンを担持した後，振とう式オートクレーブを用いて AH-ARの水素化分解反応を行って触媒性能を評価した。

\section{2. 実験}

\section{1. 触媒調製}

\subsubsection{USY ゼオライトへのAl再挿入}

出発原料には, 高 Si/A1 比 USYゼオライト（以下, USY2, 東ソー, HSZ-390HUA, $\mathrm{Si} / \mathrm{Al}=130, \mathrm{Al} / \mathrm{Si}=0.008$; 以後, 必要 に応じ $\mathrm{Al} / \mathrm{Si}$ 比も表記）を用いた。 $\mathrm{Al}$ 再挿入はアルミン酸ナト リウムを用いて以下の二つの方法で行った。第一の方法 (以下, 直接処理法) では, USY2 粉末 $(30 \mathrm{~g})$ にアルミン酸ナトリウ 么 (和光純薬工業, 一級) の水溶液 $\left(900 \mathrm{~cm}^{3}\right)$ を加え $50^{\circ} \mathrm{C}$ で 3 時間混合かくはんした。アルミン酸ナトリウム水溶液濃度は 0.035 0.085 mol / /の範囲で検討した。第二の方法 ${ }^{18)}$ (以下，ア ルコール法) では, アルミン酸ナトリウム水溶液を加える前に, USY2 粉末 $(30 \mathrm{~g})$ を室温 $\left(25^{\circ} \mathrm{C}\right)$ で真空排気した後, エチル アルコール $(25 \mathrm{~g})$ をノズル付注入バルブから噴霧含浸させた。 ついで, 均一なスラリー状態となったゼオライト粉末に対して 直接処理法と同様にアルミン酸ナトリウム水溶液処理を行っ た。アルミン酸ナトリウム水溶液処理後のゼオライトスラリー は, 万別後, イオン交換水 $(2 l)$ で水洗し, 乾燥 $\left(120^{\circ} \mathrm{C}\right) し$ た。

次に, $\mathrm{Na}^{+}$型になったゼオライトを再度 $\mathrm{H}^{+}$型とし, 残存する 無定形アルミノシリケートとアルミナを除去するために, 硫酸 アンモニウム水溶液処理と希硫酸処理を行った。まず， 0.4 $\mathrm{mol} / \mathrm{l}$ の硫酸アンモニウム水溶液中で $50^{\circ} \mathrm{C}, 1$ 時間かくはん処理 した後, 万別, 水洗 $(2 l)$, 乾燥 $\left(120^{\circ} \mathrm{C}\right)$, 焼成 $\left(500^{\circ} \mathrm{C}, 2\right.$ 時 間）した。ついで, $0.05 \mathrm{~mol} / \mathrm{l}$ の希硫酸水溶液中で $50^{\circ} \mathrm{C}, 1$ 時間 かくはん処理した後, 万別, 水洗 $(2 l)$, 乾燥 $\left(120^{\circ} \mathrm{C}\right)$, 焼成

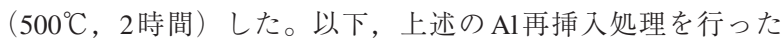

USYゼオライトをUSY2A1 と記す。

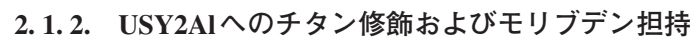

USY2Alのチタン修飾法としては, 第2 報12) と同様の硫酸チ タン水溶液処理法およびチタンアルコキシドを用いる方法 ${ }^{18)}$ を検討した。硫酸チタン水溶液処理法では, 酸性硫酸チタン (IV) 水溶液（0.05 mol $/ l, p H=1)$ を用いてUSY ゼオライトを 処理し, 超微粒子チタニアを担持した ${ }^{10)}$ 。チタンアルコキシド を用いる方法では, まずアルゴン雰囲気中でゼオライト粉末 $(10 \mathrm{~g})$ にチタンテトライソプロポキシドのエチルアルコール 溶液（15 wt\%） $100 \mathrm{ml}$ を加え, $25^{\circ} \mathrm{C}$ で2時間かくはんしなが ら浸せきした。ついで, 加圧ろ別, 乾燥 $\left(120^{\circ} \mathrm{C}, 2\right.$ 時間), 焼 成 $\left(500^{\circ} \mathrm{C}\right.$ ， 3 時間）して, チタン修飾ゼオライトを得た。

モリブデン担持は前報10,12) と同様の条件下，パラモリブデ ン酸アンモニウム水溶液を用いて平衡吸着法で行った。以下, チタン修飾USY2A1にモリブデンを担持した触媒をMTAZと記 し，USY2に平衡吸着法でモリブデンを担持した触媒を MUSY2 と記す。また, 前報10),12) で用いた Si/A1 比の低いUSY1 (東ソー, HSZ-330HUA, $\mathrm{Si} / \mathrm{Al}=3.17, \mathrm{Al} / \mathrm{Si}=0.315$ ) に上記条 件で，チタン修飾，モリブデン担持して調製したUSYゼオラ イトをMTZ，チタン修飾を行わずにモリブデン担持して調製 したUSYゼオライトをMUSY1 と記す。

\section{2. 各種ゼオライト触媒のキャラクタリゼーション}

固体酸性質, 結晶化度, 比表面積測定は第 1 報 ${ }^{10)}$ と同じ方法 で行った。また， ゼオライト中の $\mathrm{Al}$ 掞よび $\mathrm{Si}$ の化学結合状態 をNMR 測定により求めた。測定試料はあらかじめ飽和水蒸気 中に 24 時間保持し, 十分に水和した後, 既報 ${ }^{10)}$ と同様に固体 NMR装置（Burker，MSL-400）を用いてMASNMRスペクトル を測定した。 ${ }^{27} \mathrm{Al}-\mathrm{MASNMR}$ 測定は, 室温, 回転数 $10 \mathrm{kHz}$, 積 算回数 1024 で行った。化学シフト $55 \mathrm{ppm}$ 付近を 4 配位, $0 \mathrm{ppm}$ 付近を6配位として, その面積比から各 $\mathrm{Al}$ 配位数の比率を求め た。 ${ }^{29} \mathrm{Si}-M A S N M R$ 測定は, 回転数 $5 \mathrm{kHz}$, 積算回数 2048 で行 い, ${ }^{29} \mathrm{Si}-\mathrm{MASNMR}$ スペクトルを波形分離し, その面積比から $\mathrm{Si} / \mathrm{Al}$ 比を求めた。

\section{3. 常圧残油の水素化分解反応}

各触媒の水素化分解活性評価は, 既報10) と同じ AH-AR を原 料油とし, 内容積 $140 \mathrm{ml}$ の振とう式オートクレーブを用いて 行った。反応は, 原料油 $10 \mathrm{~g}$, 触媒 $1 \mathrm{~g}$ (200 mesh 以下, 未硫 化）を上記オートクレーブに仕込み, 水素初期圧 $9.8 \mathrm{MPa}$, 反 応温度 $410^{\circ} \mathrm{C}$, 反応時間 3 12 時間で行った。また, 比較実験 として, 水素化分解活性を持たない非担持水素化触媒 $\left(\mathrm{MoS}_{2}\right)$ の前駆体である油溶性モリブデン化合物（molybdenum dithiocarbamate, $\left(\mathrm{R}_{2} \mathrm{NC}\right)_{2} \mathrm{~S}_{6} \mathrm{Mo}_{2} \mathrm{O}_{2}, \mathrm{R}=\mathrm{C}_{8} \mathrm{H}_{17}$, 以下 $\left.\mathrm{MoDTC}\right)$ を用い た反応を行った。

\section{3. 結果と考察}

3.1. Al 再挿入 USY ゼオライトのキャラクタリゼーション

Table 1 に2 種類のUSYゼオライトの物性比較を示す。 USY2 はUSY1 と比較して, Si/A1 比が高く, 酸量は $1 / 150$ 程度 である。また, 結晶化度が高く, 単位格子サイズが小さいこと から，ゼオライト骨格内にはほとんど $\mathrm{Al}$ が存在しないことが わかる。さらに, USY1 と比べてメソポア量が多く, 脱 Al工程 でメソポアが発達したことを示唆している。 
Table 1 Physical Properties of USY Zeolites

\begin{tabular}{|c|c|c|c|c|c|c|c|c|}
\hline & \multirow{2}{*}{$\begin{array}{c}\mathrm{Si} / \mathrm{Al} \\
{[\mathrm{mol} / \mathrm{mol}]}\end{array}$} & \multirow{2}{*}{$\begin{array}{c}\mathrm{Al} / \mathrm{Si} \\
{[\mathrm{mol} / \mathrm{mol}]}\end{array}$} & \multirow{2}{*}{$\begin{array}{l}\mathrm{RC}^{\mathrm{a})} \\
{[\%]}\end{array}$} & \multirow{2}{*}{$\begin{array}{l}\mathrm{UD}^{\mathrm{b})} \\
{[\mathrm{nm}]}\end{array}$} & \multirow{2}{*}{$\begin{array}{l}\mathrm{SA}^{\mathrm{c})} \\
{\left[\mathrm{m}^{2} / \mathrm{g}\right]}\end{array}$} & \multicolumn{2}{|c|}{ Mesopores $^{\mathrm{d})}$} & \multirow{2}{*}{$\begin{array}{l}\text { Acidity }{ }^{\mathrm{e})} \\
{[\mathrm{mmol} / \mathrm{g}]}\end{array}$} \\
\hline & & & & & & {$\left[\mathrm{m}^{2} / \mathrm{g}\right]$} & {$[\mathrm{m} / \mathrm{g}]$} & \\
\hline USY2 & 130 & 0.008 & 101 & 2.427 & 677 & 101 & 0.248 & 0.006 \\
\hline USY1 & 3.15 & 0.317 & 87 & 2.438 & 626 & 57 & 0.136 & 0.984 \\
\hline
\end{tabular}

a) Relative crystallinity relative to $\mathrm{NaY}(100 \%)$.

b) Unit cell dimension determined by XRD.

c) Surface area determined by $\mathrm{N}_{2}$ adsorption (BET).

d) External surface area of pores with diameters $>2 \mathrm{~nm}$ calculated by the BJH method.

e) Zeolitic acidity determined by measuring the high temperature peak area at about $330^{\circ} \mathrm{C}$ in the $\mathrm{NH}_{3}-\mathrm{TPD}$ spectra.

Table 2 Physical Properties of Realuminated USY2 Zeolites

\begin{tabular}{lccccccc}
\hline & $\begin{array}{c}\text { Preparation } \\
\text { method }\end{array}$ & $\begin{array}{c}\left.\mathrm{NaAlO}_{2}{ }^{\mathrm{c}}\right) \\
{[\mathrm{mol} / l]}\end{array}$ & $\mathrm{RC}^{\mathrm{d})}$ & $\begin{array}{c}\mathrm{SA}^{\mathrm{e})} \\
{\left[\mathrm{m}^{2} / \mathrm{g}\right]}\end{array}$ & $\begin{array}{c}\mathrm{Si} / \mathrm{Al} \\
{[\mathrm{mol} / \mathrm{mol}]}\end{array}$ & $\begin{array}{c}\mathrm{Al} / \mathrm{Si} \\
{[\mathrm{mol} / \mathrm{mol}]}\end{array}$ & $\begin{array}{c}\text { Acidity }{ }^{\mathrm{f}} \\
{[\mathrm{mmol} / \mathrm{g}]}\end{array}$ \\
\hline USY2 & - & - & 101 & 677 & 130 & 0.008 & 0.00 \\
USY2Al-1 & $\mathrm{EtOH}^{\mathrm{a})}$ & 0.035 & - & 671 & 17 & 0.058 & 0.23 \\
USY2Al-2 & $\mathrm{EtOH}$ & 0.055 & - & 656 & 29 & 0.034 & 0.26 \\
USY2Al-3 & EtOH & 0.070 & 81 & 637 & 20 & 0.051 & 0.29 \\
USY2Al-4 & EtOH & 0.075 & 70 & 614 & 19 & 0.052 & 0.31 \\
USY2Al-5 & EtOH & 0.080 & 68 & 617 & 10 & 0.104 & 0.33 \\
USY2Al-6 & EtOH & 0.085 & 30 & 458 & 15 & 0.068 & 0.30 \\
USY2Al-7 & direct ${ }^{\mathrm{b})}$ & 0.050 & 63 & 683 & 30 & 0.033 & 0.21 \\
USY2Al-8 & direct & 0.075 & 2 & 354 & 10 & 0.097 & 0.26 \\
USY2Al-9 & direct & 0.085 & 0 & 212 & 11 & 0.088 & - \\
\hline
\end{tabular}

a) USY2 was treated by $\mathrm{NaAlO}_{2}$ after adsorption of EtOH. b) USY2 was directly treated by $\mathrm{NaAlO}_{2}$.

c) Concentration of $\mathrm{NaAlO}_{2}$ used for realumination. d) Relative crystallinity relative to $\mathrm{NaY}(100 \%)$.

e) Surface area determined by $\mathrm{N}_{2}$ adsorption (BET).

f) Zeolitic acidity determined by measuring the high temperature (at about $300^{\circ} \mathrm{C}$ ) peak area in the $\mathrm{NH}_{3}$ - TPD spectra.

Table 2 は各種条件下で調製した $\mathrm{Al}$ 再挿入ゼオライト （USY2Al）の物性を示す。直接処理法では，アルミン酸ナトリ ウム水溶液濃度の増大（USY2Al-7〜USY2Al-9）に伴って Si/Al 比が低下した。同時に酸量の増加が認められたが，結晶化度， 比表面積は低下した。特に，アルミン酸ナトリウム濃度が $0.075 \mathrm{~mol} / /$ 以上ではゼオライト結晶構造が破壊されていること がわかる。すなわち，直接処理法では，これまでに報告された 結果 ${ }^{17)}$ と同様, 高 Si/A1 比USY のゼオライト結晶構造を維持し ながら新たな酸点を導入することは困難であることが確認され た。

アルコール法の場合は，アルミン酸ナトリウム水溶液濃度の 増大（USY2Al-1〜USY2Al-6）に伴って結晶化度，比表面積は 徐々に低下するが，アルミン酸ナトリウム濃度 $0.075 \mathrm{~mol} / /$ 以下 （USY2A1-1４）では70\% 以上の結晶化度が維持されていた。 酸量はアルミン酸ナトリウム水溶液濃度の増大に伴って増加 し, $0.075 \mathrm{~mol} / /$ 以上（USY2Al-4〜6）では $0.3 \mathrm{mmol} / \mathrm{g}$ 以上の固 体酸点の発現が認められた。第 1 報10) では残油水素化分解に適 当な酸点密度として, $\mathrm{A} 1 / \mathrm{Si}$ 比 $0.05 \sim 0.1$ ( $\mathrm{Si} / \mathrm{Al}$ 比 10〜20), $\mathrm{NH}_{3}$-TPD酸量 $0.3 \sim 0.5 \mathrm{mmol} / \mathrm{g}$ 程度と考察した。ゼオライト含 有水素化分解触媒の優れた特性はゼオライトの結晶構造に起因 することを考慮し，上記範囲の酸量を有し，結晶化度 $70 \%$ を 維持しているUSY2Al-4を中心として, 以下詳細な検討を行っ た。

Fig. 1 はUSY2，USY2Al-4 および参照試料であるUSY1の細 孔分布を示す。USY1ではメソポアのほとんどは脱アルミ処理

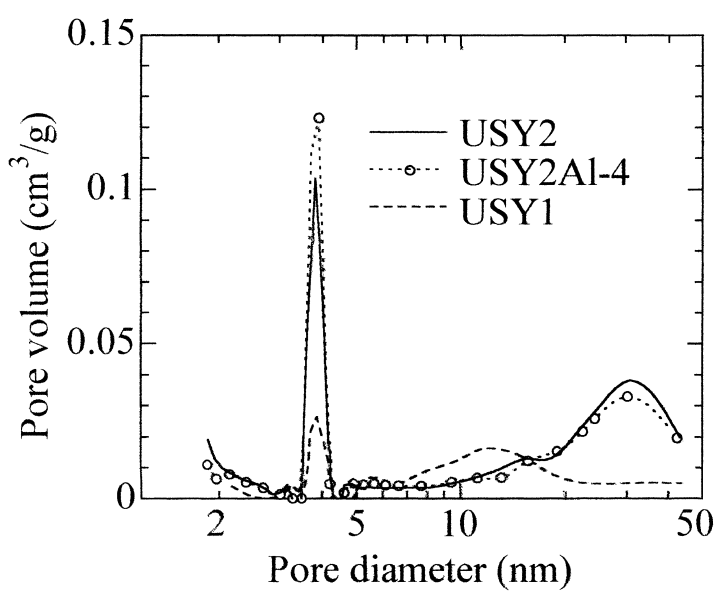

Fig. 1 Pore Distribution Profiles of USY2, USY2Al-4 and USY1

後の $\mathrm{Y}$ 型ゼオライトに特徵的な約 $4 \mathrm{~nm}$ のメポア19) であり, わずかに $10 \mathrm{~nm}$ 以上のメソポアが認められる。USY2はUSY1 と比較して, 約 $4 \mathrm{~nm}$ のメン゚ア量が多く, さらに20 50 nm のメソポア量が多い。この結果は, USY2がゼオライト骨格か らの脱 $\mathrm{Al}$ に伴って生成する約 $4 \mathrm{~nm}$ のメソポアに加えて，この メソポアが互いに連結して二次的に形成した $20 \sim 50 \mathrm{~nm}$ 付近の メソポアを有していることを示している。また，USY2Al-4の 細孔構造はUSY2 とほほ等しく, Al再挿入によって細孔構造が 


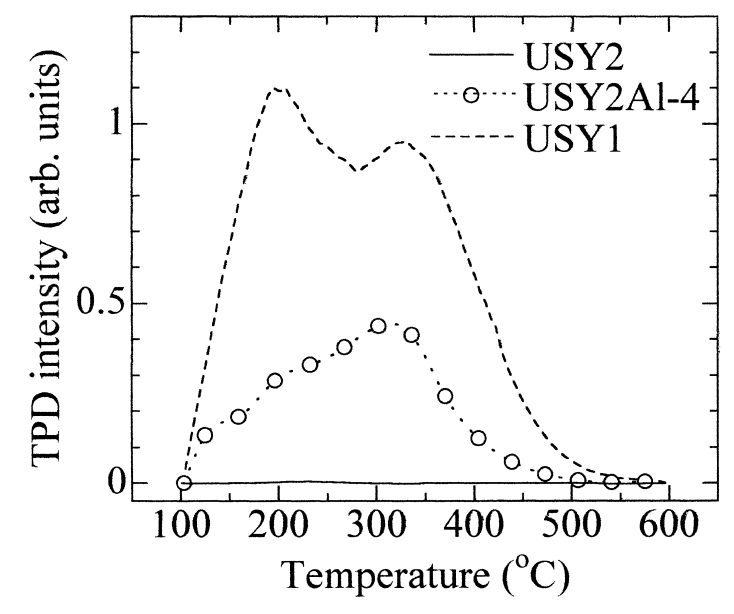

Fig. $2 \mathrm{NH}_{3}$-TPD Spectra of USY2, USY2Al-4 and USY1

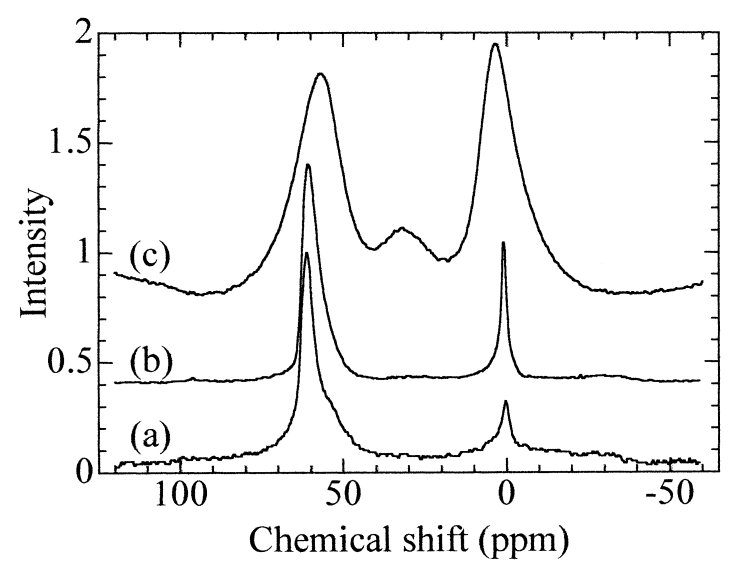

(a) USY2Al-4, (b) USY1, (c) Amorphous $\mathrm{SiO}_{2}-\mathrm{Al}_{2} \mathrm{O}_{3}$.

Fig. $3{ }^{27}$ Al-MASNMR Spectra of Zeolites

変化していないことがわかる。

Fig. 2 はUSY2, USY2A1-4 およびUSY1の $\mathrm{NH}_{3}$-TPD（temperature programmed desorption）スペクトルを示す。 $\mathrm{Al}$ 再挿入前の USY2 はAlをほとんど含んでいないため $\mathrm{NH}_{3}-\mathrm{TPD}$ スペクトル にピークは観測されず，酸点はほとんど存在しない。USY1は 第 1 報 ${ }^{10)}$ で報告の通り骨格外 $\mathrm{Al}$ を含んでいるため，ゼオライ ト状の構造に取り込まれた $\mathrm{Al}$ に由来する高温ピーク 20),21) $\left(\right.$ ピーク温度約 $\left.330^{\circ} \mathrm{C}\right)$ に加えて, 骨格外のアルミナあるいは

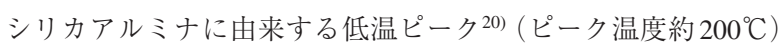
を示す。USY2Al-4の主ピークは高温ピークとなっており，ア

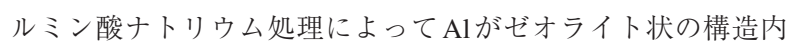
に取り达まれたことを示している。

Fig. 3はUSY2Al-4, USY1および無定形シリカアルミナの ${ }^{27}$ Al-MASNMR スペクトルを示す。USY2Al-4（Fig. 3(a)）, USY1（Fig. 3(b)）はともに0 ppm付近および $60 \mathrm{ppm}$ 付近に ピークを示す。前者はゼオライト骨格外の6 配位 $\mathrm{Al}$ に，後者は ゼオライト骨格内の4配位 Al に帰属される22)。USY1では6配 位 $\mathrm{A} 1$ ピークの相対強度比 $\left(I_{@ 0} /\left(I_{@ 0}+I_{@ 60}\right)\right)$ が約 0.4 であるのに

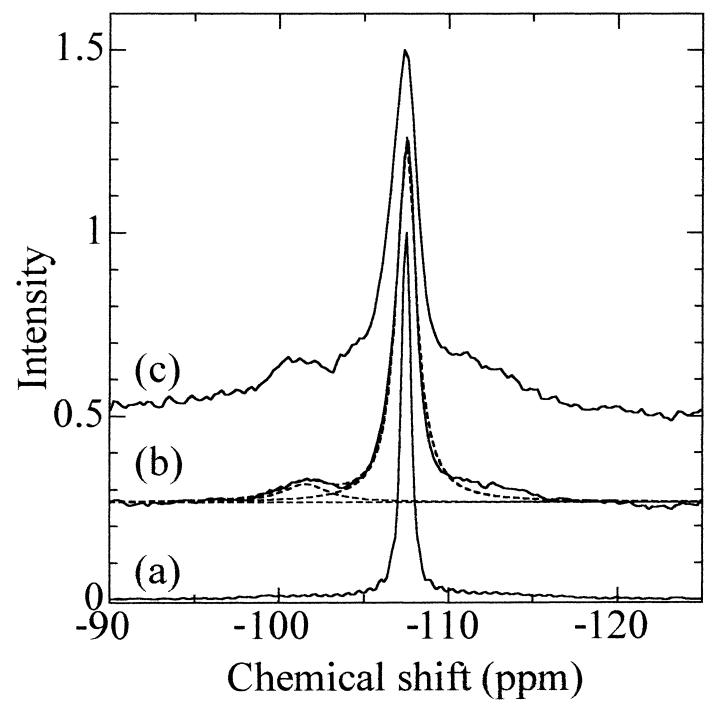

(a) USY2, (b) USY2A1-4, (c) USY2Al-4 before washing with $\mathrm{H}_{2} \mathrm{SO}_{4}$.

Fig. $4{ }^{29}$ Si-MASNMR Spectra of Zeolites

対して, USY2Al-4では 0.08 となっており, USY2Al-4中の Al の大部分は4配位構造を形成していることを示している。無定 形シリカアルミナ（Fig. 3(c)）は 0 ppm, 35 ppm, 55 ppmに ピークを示し，4配位 $\mathrm{A} 1$ に帰属されるピーク（55 ppm）はゼオ ライト骨格中の $\mathrm{A} 1$ より約 $5 \mathrm{ppm}$ 低磁場側に現れている。 USY2Al-4のスペクトルに見られる4配位ピークは高磁場側に

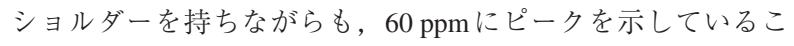
とから, USY2Al-4中の 4 配位 Alの大部分は無定形シリカアル ミナではなくゼオライト骨格に取り込まれていると推察され る。

Fig. 4 はUSY2 お方よび硫酸洗浄前後の USY2Al-4 の ${ }^{29}$ Si-MASNMRスペクトルを示す。USY2（Fig. 4(a)）は $\mathrm{Al}$ と結合してい ない $\mathrm{Si}(\mathrm{Si}(0 \mathrm{Al}))$ に帰属されるー107.46 ppmにのみピークを示 す22)。一方, USY2Al-4（Fig. 4(b)）のスペクトルには, $\mathrm{Si}(0 \mathrm{Al})$ に帰属されるピークに加え, $\mathrm{Si}(1 \mathrm{Al})$ に帰属されるピークが -101.57 ppmに認められている。両ピークの面積比から求めた $\mathrm{Si} / \mathrm{Al}$ 比は $18(\mathrm{Al} / \mathrm{Si}=0.055)$ であり, 化学分析值 $(\mathrm{Si} / \mathrm{Al}$ 比=19) と極めて近く, ほとんどの $\mathrm{Al}$ はゼオライト結晶骨格の一部に なっていることを示している。

硫酸洗浄前の USY2A1-4（Fig. 4(c)）は，-101.57 ppm と -107.46 ppmのピークに加えて， - 110〜 - 115 ppmに無定形 シリカに帰属されると考えられるショルダーが見られる。この 結果は, $\mathrm{Al}$ 再挿入中に一部無定形のシリカアルミナが生成す るが, 硫酸洗浄によってアルミナとともに除去されることを示 している。以上, ${ }^{29} \mathrm{Si}$-MASNMRの結果と ${ }^{27} \mathrm{Al}$-MASNMRの結 果は良く一致して扮り, 硫酸洗浄したUSY2Al-4中の Alのほと んどはゼオライト骨格の一部になっていると結論される。

キャラクタリゼーションの結果を総合すると, 次の理由によ りアルコール法ではUSYゼオライトの顕著な結晶破壊を起こ さずに $\mathrm{Al}$ がゼオライト骨格に再挡入されたと結論される。

アルミン酸ナトリウム水溶液処理の前工程として行ったエチ 
Table 3 Chemical Analysis of Mo Loaded Ti-modified Zeolite Catalysts

\begin{tabular}{lccccc}
\hline & Zeolite & $\begin{array}{c}\mathrm{Ti} \\
\text { modification }\end{array}$ & $\begin{array}{c}\mathrm{Ti} / \mathrm{Si} \\
{[\mathrm{mol} / \mathrm{mol}]}\end{array}$ & $\begin{array}{c}\mathrm{Al} / \mathrm{Si} \\
{[\mathrm{mol} / \mathrm{mol}]}\end{array}$ & $\begin{array}{c}\mathrm{Mo} / \mathrm{Si} \\
{[\mathrm{mol} / \mathrm{mol}]}\end{array}$ \\
\hline MUSY2 & USY2 & - & - & 0.0068 & 0.0004 \\
MTAZ1 & USY2Al-4 & $\mathrm{Ti}\left(\mathrm{SO}_{4}\right)_{2}$ & 0.007 & 0.016 & 0.004 \\
MTAZ2 & USY2Al-4 & $\mathrm{Ti}(\mathrm{OR})_{4}$ & 0.031 & 0.025 & 0.016 \\
MTAZ3 & USY2Al-8 & $\mathrm{Ti}(\mathrm{OR})_{4}$ & 0.035 & 0.008 & 0.015 \\
MTZ & USY1 & $\mathrm{Ti}\left(\mathrm{SO}_{4}\right)_{2}$ & 0.070 & 0.036 & 0.009 \\
MUSY1 & USY1 & - & - & 0.242 & 0.032 \\
\hline
\end{tabular}

Table 4 Hydrocracking of AH-AR on Various Catalysts

\begin{tabular}{|c|c|c|c|c|c|c|c|c|}
\hline \multirow{2}{*}{ Catalyst } & \multirow{2}{*}{$\begin{array}{l}\text { R. time } \\
{[\mathrm{h}]}\end{array}$} & \multirow{2}{*}{$\begin{array}{c}\text { AR conv. } \\
{[\%]}\end{array}$} & \multicolumn{3}{|c|}{ Yield [\%] } & \multirow{2}{*}{$\begin{array}{c}\text { Asp conv. } \\
{[\%]}\end{array}$} & \multirow{2}{*}{$\begin{array}{l}\text { HDS } \\
{[\%]}\end{array}$} & \multirow{2}{*}{$\begin{array}{c}\Delta \mathrm{H}_{2}{ }^{\mathrm{a})} \\
{[\%]}\end{array}$} \\
\hline & & & $\mathrm{Gas}^{\mathrm{b})}$ & $\mathrm{Naph}^{\mathrm{c})}$ & $\mathrm{MD}^{\mathrm{d})}$ & & & \\
\hline MUSY2 & 6 & 25 & 3 & 2 & 20 & 55 & 41 & 2.75 \\
\hline MTAZ1 & 6 & 40 & 4 & 6 & 31 & 68 & 77 & 2.85 \\
\hline \multirow[t]{2}{*}{ MTAZ2 } & 6 & 53 & 3 & 16 & 34 & 84 & 88 & 3.21 \\
\hline & 3 & 42 & 2 & 11 & 28 & 72 & 78 & 2.67 \\
\hline \multirow[t]{2}{*}{ MTAZ3 } & 6 & 33 & 4 & 2 & 27 & 82 & - & 3.16 \\
\hline & 8 & 50 & 4 & 19 & 27 & 90 & - & 3.37 \\
\hline MUSY1 & 6 & 70 & 17 & 44 & 10 & 43 & 69 & 5.58 \\
\hline \multirow[t]{2}{*}{ MTZ } & 6 & 69 & 6 & 21 & 42 & 80 & 87 & 3.97 \\
\hline & 3 & 52 & 5 & 22 & 25 & 52 & 59 & 2.96 \\
\hline MoDTC & 6 & 31 & 2 & 4 & 25 & 57 & 48 & 2.44 \\
\hline MoDTC & 12 & 43 & 3 & 8 & 32 & 100 & - & 3.56 \\
\hline
\end{tabular}

a) Hydrogen consumption (weight $\%$ basis). b) C1-C5. c) BP: IBP- $150^{\circ} \mathrm{C} . \quad$ d) BP: $150^{\circ} \mathrm{C}-343^{\circ} \mathrm{C}$. Reaction conditions : $410^{\circ} \mathrm{C}, P_{\mathrm{H}_{2}}=9.8 \mathrm{MPa}$ (cold charge), cat $/ \mathrm{oil}=0.1 \mathrm{~g} / \mathrm{g}$.

ルアルコール処理においてゼオライトのマイクロポア,メソポ アはエチルアルコールで満たされる。低濃度のアルミン酸ナト リウム水溶液処理の場合, エチルアルコールと水が置換されや すいメソポア表面付近でのみアルミン酸イオンがゼオライト表 面に接近し, $\mathrm{Al}$ 再挿入が起こるが, マイクロポア内ではゼオ ライト表面は疎水性のエチル基と強い親和性をもつためアルミ ン酸ナトリウムが接近できず, $\mathrm{Al}$ 再挿入は進行しない。高濃 度のアルミン酸ナトリウム水溶液処理では, マイクロポア内に もアルミン酸イオンが次第に侵入し $\mathrm{Al}$ 再挿入が進行する。

Table 3は, USY2, USY2A1 掞よびUSY1をチタン修飾し, 続いてモリブデンを担持したゼオライト触媒（MTAZ, MTZ), USY2およびUSY1にチタン修飾を行わずにモリブデンを平衡 吸着担持したゼオライト触媒（MUSY2, MUSY1）の化学分析 值を示す。USY2Al-4 硫酸チタン水溶液処理によってチタン 修飾したMTAZ1 は他のチタン修飾触媒と比較してチタン修飾 量（Ti/Si）が著しく少ない。チタンアルコキシドを用いた場合 (MTAZ2, MTAZ3) は, ゼオライト内に存在する水分によっ てアルコキシドが加水分解し, 生成したチタニア前駆体がゼオ ライト表面に沈積するため, $\mathrm{Al}$ 再挿入ゼオライトであっても 多量のチタニアが担持されたと考えられる。

いずれの MTAZ触媒でも Al/Si 比（0.008～0.025）はモリブデ ン担持前の USY2Al-4 (0.052), USY2A1-8（0.097）と比べて低 い。この原因は, 再挿入された $\mathrm{Al}$ が酸性条件 $(\mathrm{pH}=$ 約 2) で 行われるモリブデン平衡吸着中に溶出したためと考えられる。 特に, チタン修飾を硫酸チタン水溶液処理で行った場合, 酸性 水溶液中での処理が繰り返されるため $\mathrm{Al} / \mathrm{Si}$ 比がさらに低く
なったと考えられる。

モリブデン担持量（Mo/Si） は, MUSY1 (0.032)>MTAZ2 $(0.016)>\operatorname{MTAZ3}(0.015)>\operatorname{MTZ}(0.009)>\operatorname{MTAZ1}(0.004)>$ MUSY2（0.0004）の順となった。酸性（pH=2）条件下での平 衡吸着法ではモリブデンはゼオライト骨格には担持されず，チ タニアおよびアルミナ上に担持されることが報告されてい る23),24)。このため, USY2にはモリブデンはほとんど担持され ない。また, チタン修飾量の少ないMTAZ1ではMTAZ2 と比 較してモリブデン担持量が少なくなったと考えられる。MTZ はMTAZ2, MTAZ3 と比較してチタン修飾量が多いにもかかわ らずモリブデン担持量が少ない。この理由は明らかではないが, アルコキシドを用いて修飾したチタニアが硫酸チタン処理して 修飾したチタニアと比べてモリブデンを平衡吸着しやすい可能 性を示唆している。チタン修飾を行っていないUSY1へのモリ ブデン担持量が高い理由は, Fig. 3 の NMRの結果が示すよう に, 骨格外アルミナ上にモリブデンが平衡吸着担持されたため と考えられる。

前報6)の検討では, $\mathrm{MTZ}(\mathrm{Mo} / \mathrm{Si}=0.009)$ は $\mathrm{AH}-\mathrm{AR} の$ 水素 化分解触媒として十分な水素化機能を示した。したがって, 担 持量の観点からはMTAZ2, MTAZ3は十分量のモリブデンを担 持していると判断される。なお，モリブデン担持による結晶化 度の低下は $10 \%$ 程度であることが確認されている ${ }^{10) 。 ~}$

\subsection{MTAZの触媒性能}

Table 4 はMUSY2, MTAZ, MTZおよびMoDTC触媒のAH$\mathrm{AR}$ 水素化分解反応結果を示す。反応時間 6 時間における $\mathrm{AR}$ 分 解率（AR Conv.）を比較すると, MUSY1 (70)>MTZ (69)> 
$\operatorname{MTAZ2}(53)>\operatorname{MTAZ1}(40)>\operatorname{MTAZ3}(33)>\operatorname{MoDTC}(31)>$ MUSY2（25）の順となった。MoDTCを除き，序列はゼオライ トの $\mathrm{A} 1 / \mathrm{Si}$ 比の序列（Table 3） と一致した。ゼオライトの固体 酸量はゼオライト骨格の $\mathrm{Al} / \mathrm{Si}$ 比に比例すると考えられる。し たがって, これらの触媒間で $\mathrm{Al} / \mathrm{Si}$ 比の序列, 酸量の序列, AR 分解率の序列が一致していることは, MTAZでは再挿入 $\mathrm{Al}$ が 酸点としてAR分解に機能していること，また酸点導入による 分解機能向上に対応する水素化機能が付与されていること ${ }^{10)}$ を示唆している。一方, 高い Al/Si 比 (0.242) を有する MUSY1がMTZ（A1/Si 比 0.036）とほぼ同程度のAR分解率を示 すのはMUSY1 中の Alの多くが骨格外アルミナを形成し, 酸点 として機能していないためと考えられる。

反応時間 6 時間における脱アスファルテン率（Asp Conv.） の序列はMTAZ2（84）ＭTAZ3（82）～MTZ（80）>MTAZ1 (68) >MoDTC（57）〜MUSY2（55）>MUSY1（43）となった。 MTZ，MTAZがMUSY1より高い活性を示している原因は，チ タン修飾によりモリブデンが高分散担持され，水素化活性が向 上した結果と考えられる ${ }^{10)}$ 。また, MTAZ1の脱アスファルテ ン率が他の MTAZ触媒より低い原因はモリブデン担持量が少 ないためと考えられる。すなわち，これまでに報告されている ように ${ }^{25), 26)}$, 反応温度 $400^{\circ} \mathrm{C}$ 以上では脱アスファルテンには触 媒の水素化機能が重要であり, 固体酸点に基づく分解機能の役 割は小さいと考えられる。

脱硫活性に执いてもMTAZ1，MTAZ2 はMUSY1，MUSY2 と 比べて高い值を示した。以上, MTAZ2はMUSY2 と比較して, $\mathrm{AR}$ 分解率, アスファルテン転化率, 脱硫率いずれに抏いても より高い性能を示しており, $\mathrm{Al}$ 再挿入による酸点導入の効果 に加えて，水素化機能も向上したことを示している。前報10),12) では, チタン修飾ゼオライトの高い水素化分解機能の原因が千 タニア担持モリブデン触媒の高い水素化活性 27) 29) とゼオライ 卜の分解活性の効果的な協奏作用にあることを考察した。チ夕 ニア上モリブデンの高い触媒活性については高分散性 ${ }^{30), 31)}$,

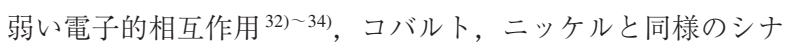

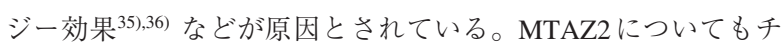
タニア上に担持されたモリブデンがこのような理由により高い 触媒活性を示したと考えられる。

Fig. 5 にAH-ARの水素化分解反応により得られた生成油の 蒸留曲線を示す。 $\mathrm{Al}$ 再挿入を行っていないMUSY2では分解反 応の進行が少なく, MoDTCを触媒として用いた水素化熱分解 反応 (Table 4) のみの場合10) と同様の蒸留曲線を示している。 MUSY1は, 沸点 $500^{\circ} \mathrm{C}$ 以下の留分に対しては高い分解率を示 すが高沸点留分の分解率は低い。また，Table 4に示すように ナフサおよびガスの収率が高く, 中間留分選択性は低い。 MTZ, MTAZ2では, 高沸点留分から中間留分にかけて全留分 にわたって分解反応が進み, 全留分の軽質化反応が起こってい ることがわかる。中間留分, ナフサ, ガスの収率を比較すると, いずれの MTZ, MTAZ触媒でもMUSY1 と比べて中間留分 （MD）収率が増加して掞り, 高い中間留分選択性が得られた ことがわかる。

重質油の水素化分解反応は複雑な反応の組合せで進行する が，主に中間留分を経てナフサ，ガスが生成する逐次反応と仮 定できると考えられている8)。したがって，ほぼ同一のAR分

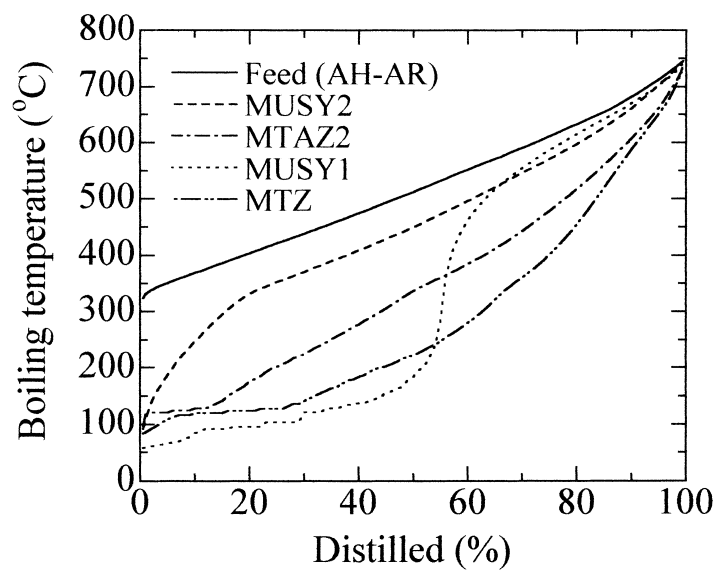

Fig. 5 Distillation Profiles of Feedstocks and Liquid Products over Various Catalysts

解率における各留分の収率により触媒選択性を比較することが できる。Table 4からわかるように, MTZを用いての反応時間 3 時間の AR 転化率 $(53 \%)$, MTAZ2 を用いての反応時間 6 時間 の AR 転化率 $(52 \%)$, MTAZ3を用いての反応時間 8 時間の AR 転化率 $(50 \%)$ はほぼ等しい。このとき, 中間留分収率は MTZが 25\%（ナフサ 22\%，ガス 5\%）であるのに対して, MTAZ2は34\%（ナフサ16\%，ガス3\%)，MTAZ3は27\%（ナ フサ 19\%，ガス 4\%）となっており，Al再挿入USYゼオライ トがより高い中間留分選択性を示している。

既報10),12) では, チタン修飾触媒が高い中間留分選択性を示 す原因は, 大容量のメソポアと酸機能制御による過分解の抑制 にあると推論した。本研究に扔ける結果は前報の推論が正し かったことを示している。すなわち, メソポアの発達した高シ リカのUSY2をべースとするUSYゼオライト触媒（MTAZ1 MTAZ3）はMUSY1 と比較して高い中間留分選択性を示した。 また，MTAZ2がMTZよりも高い中間留分選択性を示した原因 は, MTZと比べてメソポア量がより大きいことに加えて, Al 再挿入により付与した酸点が主としてメソポア表面に存在し, ナフサ, ガス生成の原因となるマイクロポア内の酸点が極めて 少ないためと考えられる。以上, MTAZのキャラクタリゼー ションおよび触媒性能評価の結果から推察したMTAZの構造 模式図をFig. 6に示す。今後, Al 再挿入 USY ゼオライトの実 用化に向けては, スケールアップが可能な $\mathrm{Al}$ 再挿入工程, チ タン修飾条件の検討が必要と考えられる。

\section{4. 結言}

残油の水素化分解反応用に開発したチタン修飾 USYゼオラ イト（MTZ）のさらなる中間留分選択性向上を目的として, メソポア容量の大きい高 $\mathrm{Si} / \mathrm{Al}$ 比 USY ゼオライトへの $\mathrm{Al}$ 再挿 入, 触媒調製 (チタン修飾およびモリブデン担持), 活性評価 を行った結果, 以下の結論が得られた。

（1）アルミン酸ナトリウム水溶液処理に先駆けてエチルアル コールに浸せきすることにより，ゼオライトの結晶構造，メソ ポア構造を保ちつつ, 高 Si/Al 比USY ゙゙オライトへの Al 再挿入 が可能であることがわかった。 


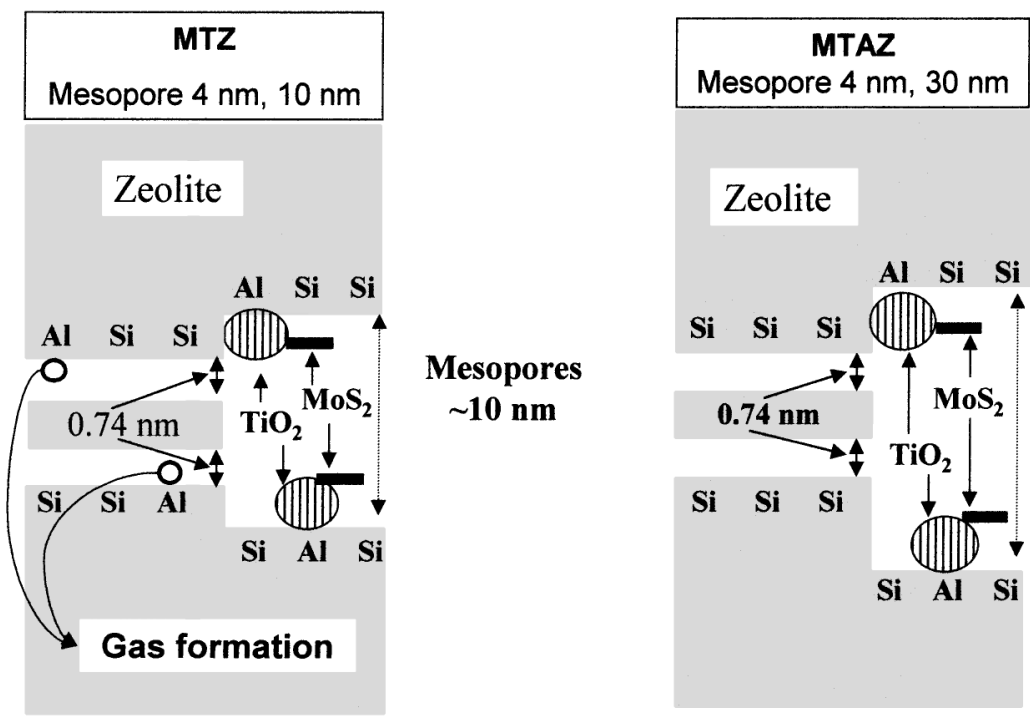

\section{Mesopores \\ $\sim 30 \mathrm{~nm}$}

Fig. 6 Schematic of MTAZ Catalysts

（2）硫酸チタン水溶液に代えてチタンイソプロポキシドのアル コール溶液を用いることにより, USY ゼオライトに再挿入し た $\mathrm{Al}$ の溶出を抑えつつチタン修飾, モリブデン担持が可能で あることがわかった。

（3）上記により調製したモリブデン担持チタン修飾USYゼオ ライト（MTAZ2）は，アルミニウム再扱入とチタン修飾を行 わないMUSY2 と比べて高いAR分解率, アスファルテン転化 率を示した。この結果は, 再挿入 $\mathrm{Al}$ にる酸点の効果とチ夕 ン修飾によるモリブデン高分散担持の効果によると考察され た。

（4）MTAZ2はMTZと比べてより高い中間留分選択性を示し た。この原因は, メソポアが豊富なことに加えて, 再挿入され た $\mathrm{Al}$ が主としてメソポア内に分布して酸点を形成し, ナフサ, ガス生成の原因となるマイクロポア内の酸点が少ないためと考 察された。

\section{謝 辞}

本研究は(財)国際石油交流センターが経済産業省の補助金事 業の一環として実施したものである。産業技術総合研究所研究 員佐藤剛一博士に有益な議論をして頂いた。ここに深謝いたし ます。

\section{References}

1) Nishikawa, T., PETROTECH, 26, (2), 142 (2003).

2) Takatsuka, T., "Handbook of Environmental Catalyst," ed. by Iwamoto, M., NTS Publishers, (2001), p. 237.

3) Nishina, T., PETROTECH, 24, (7), 549 (2001).

4) Morel, F., Kressmann, S., Harlé, V., Kasztelan, S., Stud. Surf. Sci. Catal., 106, 1 (1997).

5) Minderhoud, J. K., van Veen, J. A. R., Hagan, A. P., Stud. Surf. Sci. Catal., 127, 3 (2001).

6) Iino, A., Shokubai (Catalysts \& Catalysis), 33, 21 (1991).

7) Nita, K., Kameyama, M., Noguchi, Y., Seimiya, K., Sekiyu Gakkaishi (J. Jpn. Petrol. Inst.), 32, (3), 122 (1989).

8) Seimiya, K., Hashimoto, M., Suzuki, S., Kameyama, M.,
Noguchi, Y., Nita, K., Sekiyu Gakkaishi (J. Jpn. Petrol. Inst.), 33, (5), 52 (1990).

9) Nita, K., Nakai, S., Hidaka, S., Mibuchi, T., Shimakawa, H., Ii, K., Inamura, K., Stud. Surf. Sci. Catal., 34, 501 (1987).

10) Honna, K., Araki, Y., Enomoto, T., Yoshimoto, M., Shimada, H., J. Jpn. Petrol. Inst., 46, (4), 249 (2003).

11) Jpn. Kokai Tokkyo Koho JP2000-334305 (JP3341011).

12) Enomoto, T., Aizono, H., Ueki, H., Hashimoto, Y., Oshio, N., Honna, K., Yoshimoto, M., Shimada, H., J. Jpn. Petrol. Inst., 47, (4), 239 (2004).

13) Clarence, D. C., Cynthia, T. W. C., Joseph, N. M., Robert, F. B., Calvert, R. B., J. Am. Chem. Soc., 106, 8143 (1984).

14) Nishimura, Y., Shokubai (Catalysts \& Catalysis), 34, 232 (1992).

15) Hamdan, H., Sulikowski, B., Klinowski, J., J. Phys. Chem., 93, 350 (1989).

16) Sulikowski, B., Datha, J., Gil, B., Ptaszynski, J., Kiinowski, J., J. Phys. Chem., 101, 6929 (1997).

17) Zhang, Z., Liu, X., Xu, Y., Xu, R., Zeolites, 11, 232 (1991).

18) Jpn. Kokai Tokkyo Koho JP2002-255537 (2002).

19) Sato, K., Nishimura, Y., Honna, K., Matsubayashi, N., Shimada, H., J. Catal., 200, 288 (2001).

20) Katada, N., Niwa, M., Shokubai (Catalysts \& Catalysis), 42 , 218 (2000).

21) Niwa, M., Iwamoto, M., Segawa, K., Bull. Chem. Soc. Jpn., 59, 3735 (1986).

22) Nakata, S., Asaoka, S., Segawa, K., Nippon Kagaku Kaishi, 1989, 795 (1989).

23) Wang, L., Hall, W. K., J. Catal., 77, 232 (1982).

24) Kim, D. S., Wachs, I. E., Segawa, K., J. Catal., 149, 268 (1994).

25) Shimada, H., Yoshitomi, S., Sato, T., Matsubayashi, N., Imamura, M., Yoshimura, Y., Nishijima, A., Stud. Surf. Sci. Catal., 106, 5 (1997).

26) Byambajav, E., Ohtsuka, Y., Appl. Catal., 252, 193 (2003).

27) Shimada, H., Sato, T., Yoshimura, Y., Hiraishi, J., Nishijima, A., J. Catal., 110, 275 (1988).

28) Ramirez, J., Fuentes, S., Diaz, G., Vrinat, M., Breysse, M., Lacroix, M., Appl. Catal., 52, 211 (1989).

29) Okamoto, Y., Maezawa, A., Imanaka, T., J. Catal., 120, 29 (1989).

30) Ramirez, J., Ruiz-Ramirez, L., Cedeno, L., Hale, V., Vrinat, M., Breysse, M., Appl. Catal., A93, 163 (1993). 
31) Leliveld, R. G., van Dillen, A. J., Geus, J. W., Koningsberger, D. C., J. Catal., 171, 115 (1997).

32) Yoshinaka, S., Segawa, K., Catal. Today, 45, 293 (1998).

33) Araki, Y., Honna, K., Shimada, H., J. Catal., 207, 361 (2002).
34) Shimada, H., Catal. Today, 86, 17 (2003).

35) Ramirez, J., Cedeno, G., Busca, G., J. Catal., 184, 59 (1999).

36) Coulier, L., van Veen, J. A. R., Niemantsverdriet, J. W., Catal. Lett., 79, 149 (2002).

要旨

\title{
チタン修飾USY ゼオライトを用いた残油水素化分解触媒の開発（第3 報） Al 再挿入USY ゼオライトを用いた触媒の調製および活性評価
}

\author{
本名幸作 ${ }^{\dagger 1)}{ }^{\dagger 3}$ ，荒木泰博 ${ }^{\dagger 1)}$ ，榎本敏行 ${ }^{\dagger 1)}$ ，吉本昌雄 ${ }^{\dagger 1)}$ ，西村陽一 ${ }^{\dagger 2}$ ，島田広道 ${ }^{\dagger 2)}$
}

†1) (財) 国際石油交流センター 技術協力部高機能触媒研究室, 213-0012 川崎市高津区坂戸3-2-1KSP R\&D棟 D-12F-1237

†2)（独）産業技術総合研究所，305-0031 茨城県つくば市東1-1-1つくば中央第5

†3) (現在）299-0117 千葉県市原市青葉台6-3-5

中間留分選択性の高い残油水素化分解触媒の開発を目的とし て, メソポア容積が大きく, 高 $\mathrm{Si} / \mathrm{Al}$ 比 $(\mathrm{Si} / \mathrm{Al}=130)$ の USY ゼオライトを出発原料とする触媒を調製し, アラビアンヘビー 常圧残油（AH-AR）の水素化分解活性評価を行った。触媒調 製は，USYゼオライトをエチルアルコールに浸せきした後，

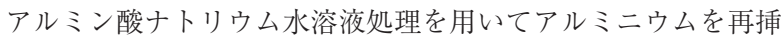
入することで固体酸点を導入した。エチルアルコール浸せきに より, $\mathrm{Al}$ 再挿入工程でのゼオライトの構造破壊が抑制される ことが分かった。ついで, チタンイソプロポキシドのエチルア
ルコール溶液を用いてチタン修飾し，さらにパラモリブデン酸 アンモニウム水溶液を用いた平衡吸着法によってモリブデンを 担持した。得られた触媒 (MTAZ) は水素化分解反応評価にお いて，前報で報告したチタン修飾USYゼオライト触媒（MTZ） よりもさらに優れた中間留分選択性を示した。MTAZの中間留 分選択性が高い原因は, メソポアが豊富であることに加えて, $\mathrm{Al}$ 再挿入が主としてメソポア表面で起こったため, ナフサ, ガス生成の原因となるマイクロポア内酸点が少ないためである と考察された。 